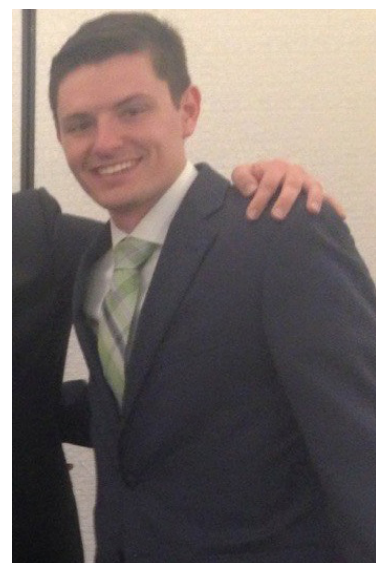

TROY GABRIEL is a fourth year Political Science major, concentrating in Global Politics. He has participated in Cal Poly's Model United Nations club, attending conferences in New York City and San Francisco. Troy wrote this paper for a Contemporary U.S. Foreign Policy class and chose this topic because of the frequency with which public opinion polls on current events are cited in the news. Finding himself curious about the effectiveness of these polls on decision-making, Troy decided to examine case studies to understand the relationship between public opinion and foreign policy decisions in America. After Troy graduates, he plans on joining the Peace Corps, teaching English, before attending graduate school. 


\title{
WILL OF THE PEOPLE: PUBLIC OPINION AND U.S. FOREIGN POLICY \\ Troy Gabriel
}

\begin{abstract}
This research paper examines how effective public opinion is at influencing U.S. foreign policy and makes predictions on what this relationship will look like in the future. The research was qualitative in nature, examining information found in speeches and remarks made by government actors as well as the general public. The research focused on two case studies; the Vietnam War and the Iraq War, and found that the top decision maker in government at the time of each conflict, namely the President, carried out policies that often disregarded public opinion entirely. The implications of this research indicate that as the U.S. attempts to retain its hegemonic status, future foreign policy decision will become less representative of the masses and will more closely resemble an oligarchy rather than a democracy.
\end{abstract}

\section{Real World Observation}

On September 10, 2014, The New York Times reported that President Barack Obama had authorized a military campaign against the Sunni militant group 
known as ISIS, or the Islamic State of Iraq and Syria. ${ }^{1}$ The authorized campaign calls for American airstrikes in Syria as well as the deployment of 475 military advisors to Iraq. ${ }^{2}$ These military advisors are being sent in order to assist the Kurdish and Iraqi forces with more training, intelligence, and equipment against these fighters. ${ }^{3}$ President Obama made it clear that these forces will not be used in any combat capacity, but will strictly be there to support U.S. allies in the region. ${ }^{4}$ This new authorization will bring the total number of American troops in Iraq to 1,600. ${ }^{5}$ The President also called on Congress to authorize the allocation of resources in order to "train and equip" the opposition forces fighting the Assad regime in Syria. ${ }^{6}$ This new authorization comes just two weeks after the President was criticized for not having a strategy to deal with the rising threat, paralleling the change in public opinion, ${ }^{7}$ with $53 \%$ of adults approving of the plan. ${ }^{8}$

This rapid change in the administration's position towards ISIS is not an outlier in the history of executive action, and it is important to put this most recent announcement into the context of recent history. A year to the day before the speech President Barack Obama gave regarding ISIS, he gave a speech discussing America's involvement Syria. ${ }^{9}$ In it, Obama argued the benefits of limited airstrikes in Syria, ${ }^{10}$ counter to the prevailing opinion of the public of noninvolvement. ${ }^{11}$ Just a few weeks earlier, Obama stated that

${ }^{1}$ Mark Landler, "Obama, in Speech on ISIS, Promises Sustained Effort to Rout Militants," The New York Times, September 10, 2014.

2 Ibid.

${ }^{3}$ Statement by the President on ISIL. The White House, September 10, 2014.

${ }^{4}$ Ibid.

5 Lander, "Obama, in Speech on ISIS."

6 "Statement by the President on ISIL." The White House

7 Lander, "Obama, in Speech on ISIS."

8 "Bipartisan Support for Obama's Military Campaign Against ISIS," Pew Research Center for People and the Press, September 15, 2014.

9 Katie Zezima, "How Obama's second Sept. 10 Syria speech in a row was different this year - and how it wasn't," The Washington Post, September 10, 2014.

${ }^{10}$ Remarks by the President in Address to the Nation on Syria. The White House, September 10, 2013.

11 "American Views on Intervention in Syria," The New York Times/CBS News Poll, September 10, 2013. 
he "will seek authorization for the use of force from the American people's representatives in Congress" and not use his executive authority. ${ }^{12}$ The choice by the president to defer the decision to Congress, and not use executive action, shows that this is not the first time Obama has entertained the public's interest in foreign policy matters. An earlier example occurred near the end of the Bush administration. In 2007, 63\% of the public was in favor of their congressional representatives voting for a bill to withdraw troops from Iraq in the next year. ${ }^{13}$ The following year, Bush announced that there would be a withdrawal of 8,000 troops by February of 2009, appearing to give in to the public's will. While Bush wielded his authority in order to appease the public, Obama left the decision up to Congress, or the people directly. ${ }^{14}$ These instances show that the quick policy decisions and changes made by executives occur regardless of the administration, and give context when looking at other historical examples.

The influence that public opinion has on the executives who make contemporary U.S. foreign policy is a very important relationship study, and has profound implications for how we understand the formulation of American foreign policy. If U.S foreign policy is always guided by the prevailing public opinion, polices can be shortsighted and overlook key issues. The tendency for policies to not be as informed if guided by public opinion can be seen in a study done by Rogers, Stuhler, and Koeing in which they find that there is a "large gap" between the opinions of knowledgeable experts and that of the general public. ${ }^{15}$ The researchers go on to make the assertion that the foreign policy opinions of experts were "specific, many-sided, analytical, and flexible," while the general public's opinions "tended to be vague and sporadic." ${ }^{16}$ On the other hand, if public opinion is not a part of the equation in U.S. foreign policy formulation, then is it still accurate to label the U.S. as a

\footnotetext{
12 Statement by the President on Syria. The White House, August 31, 2013.

13 "A Summer of Discontent with Washington," Pew Research Center for the People and the Press, August 2, 2007.

${ }^{14}$ Ewen MacAskill, "Bush limits Iraq troop withdrawal to 8,000 and orders 'quiet surge' in Afghanistan,” The Guardian September 9, 2008.

${ }^{15}$ William C. Rogers, Barbara Stuhler, and Donald Koeing, "A Comparison of Informed and General Public Opinion on U.S. Foreign Policy," The Public Opinion Quarterly, Vol. 31, No. 2 (Summer, 1967): 242-252.
}

${ }^{16}$ Ibid. 
representative democracy? It seems as if public opinion has an effect on the formulation and path of U.S. foreign policy, but it is unclear by how much of a role it plays. This uncertainty leads me to ask the following question: How effective is public opinion at influencing U.S. foreign policy?

\section{Conventional Wisdom}

The democratic ideal of a responsive, representative government illustrates the prevailing belief that public opinion matters in both domestic and foreign issues. This ideal is an essential part of American political culture, one that the public whole-heartedly believes in. For instance, in a poll conducted by World Public Opinion, $81 \%$ of respondents said that when governmental leaders are making an important decision, they "should pay attention to public opinion polls because this will help them get a sense of the public's views." ${ }^{17}$ This finding is further backed up by the principle expressed in the Universal Declaration of Human Rights, that "the will of the people should be the basis of the authority of government," with $87 \%$ of Americans agreeing. ${ }^{18}$ In a study done by the Pew Research Center for People and the Press, polling data shows that the long-range policy priorities of the general public and the Council on Foreign Relations (CFR) are similar in several key areas. ${ }^{19}$ Both believe that protecting the U.S. from terrorism is a top priority, with $83 \%$ of the public and $76 \%$ of the CFR. There is also large overlap in regard to preventing the spread of Weapons of Mass Destruction, with $73 \%$ of the public and $81 \%$ of the CFR making it a priority. ${ }^{20}$ When there is large overlap between the opinions of the public and those of policy elites, it seems clear that public opinion is effective at influencing foreign policy. However, the idealism of democracy is not always the reality of democracy, and it would be a mistake to draw such a conclusion.

This conventional wisdom is misleading because it suggests that the general public has a direct role in which policies are top priorities, when evidence

17 "American Public Says Government Leaders Should Pay Attention to Polls," World Public Opinion.org, March 21, 2008.

${ }^{18}$ Ibid.

19 "Public Sees U.S. Power Declining as Support for Global Engagement Slips: America's Place in the World 2013," Pew Research Center for the People and the Press, December 3, 2013.

${ }^{20}$ Ibid. 
suggests otherwise. Such evidence can be seen when looking at the public's opinion on the war in Iraq. At the start of the war in 2003, public support was at a high of $74 \% .{ }^{21}$ Yet just a few years later in 2007 public support for the war had dropped to $40 \%$, with a majority of $53 \%$ of the public favoring withdrawal. ${ }^{22}$ Even though the majority opinion favored a change in policy, the change did not happen for another 4 years, when the war officially ended. ${ }^{23}$ If the conventional wisdom were entirely true, the timeline of the war would have paralleled the changes in the public opinion. The fact that it didn't show that foreign policy is not always influenced by public opinion, illustrates a flaw in the conventional wisdom.

\section{Theoretical Paradigm}

To best understand the research question and the case studies presented, the research is framed using the theoretical paradigm of U.S. foreign policy known as group dynamics. This theory was defined by Dorwin Cartwright and Alvin Zander as a "field of inquiry dedicated to advancing knowledge about the nature of groups, the laws of their development, and their interrelations with individuals, other groups, and larger institutions." ${ }^{24}$ In regard to U.S. foreign policy and international relations, the theory of group dynamics is predicated on the belief that special interests or elites, not the state, influence political outcomes. ${ }^{25}$ This general beliefs leads to the other core assumptions of the group dynamics theory. The first of these core assumptions is that decision-making actors are susceptible to the influence of groupthink. ${ }^{26}$ The people in a decision-making position are constantly interacting with others in their respective groups. These interactions in the group might "exert pressures for conformity to group norms," ${ }^{27}$ an inherently bad thing, as it

\footnotetext{
${ }^{21}$ Scott Keeter, "Trends in Public Opinion about the War in Iraq, 2003-2007," Pew Research Center, March 15, 2007.

22 Ibid.

23 “Barack Obama: All US Troops to Leave Iraq in 2011,” BBC News, October 21, 2014.

${ }^{24}$ Dorwin Cartwright and Alvin Zander, "Origins of Group Dynamics," Group Dynamics, $3^{\text {rd }}$ Edition, (1968): 3-21.

25 C. Wright Mills, The Power Elite (Oxford University Press, 1956).

${ }^{26}$ Ole R. Holsti. "Models of International Relations and Foreign Policy." Diplomatic History 13 , no 1 . (1989).

27 Ibid.
} 
can "inhibit the search for information and policy options . . suppressing some forms of intragroup conflict that might serve to clarify goals, values, and opinions." ${ }^{28}$ A second core assumption of group dynamics theory is that when it comes to the group of decision-makers, "the power elite," 29 its members are from small group of "political, economic, and military men." ${ }^{30}$ According to this assumption, this group comes from "the upper third of the income and occupational pyramids," which makes this group relatively unrepresentative of the majority. It is this assumption that is most pertinent to the research presented in this paper. $^{31}$

Group dynamics, and the assumptions stated above, is the most appropriate and fitting theory to frame and explain the influence of public opinion on U.S. foreign policy. First, group dynamics' assumption that individuals or groups, not the state, influence political outcomes helps frame the case studies presented in this paper regarding decisions of Presidents during wartime. This is due to the concept of groupthink, since the policy decision makers are not interacting with the public on a daily basis, and do not view the public as their peers. The people they do interact with daily, their peers, will inherently place pressures on the decision makers to appease or conform to the group thinking, potentially having "a significant impact on the substance and quality of decisions." ${ }^{32}$ This theory has a negative viewpoint concerning the research question. The fact that the decision maker group is separate from the public opinion suggests that they therefore do not have an influence on policy formulation. The second assumption made by this theory regarding the make-up of the "power elite" further highlights its usefulness when framing the answer to the research question. By assuming that the power elite are comprised of an unrepresentative minority of industry leaders, the ineffectiveness of the public opinion's influence becomes clear. How can public opinion compete with the influence that this small group of people have, a group who are interacting with each other every day and developing personal relationships? It is because of these assumptions that

\footnotetext{
28 Ibid.

${ }^{29}$ Mills, The Power Elite

${ }^{30}$ Ibid.

31 Ibid.

${ }^{32}$ Holsti, "Models of International Relations and Foreign Policy."
} 
the theory of group dynamics best frames the answer to the research question presented in this paper.

\section{The Vietnam War}

The military operation in Vietnam that lasted from November 1955 until April 1975 is one of notoriety in United States history. It was a timed filled with protests and civil disobedience, as well as a period in which the leaders of the U.S. faced the challenge of balancing policy they deemed appropriate and the policy the public demanded. In retrospect, most people, public and policy elite, consider the Vietnam engagement as a mistake, one some deem an "important history lesson." 33 Yet when this was a contemporary issue, that sentiment was not as wide spread, with many of the policy elites deeming the war effort a righteous one based on democratic principles. ${ }^{34}$ Due to the contradictory relationship between the public and the policy elites during the Vietnam War, this period is important to consider when attempting to answer the research question.

In order to study this relationship properly, it will be important to approach this case study in a chronological fashion. By observing how the war developed over time, and the policy decisions that affected it, the cause and effect relationship between the public opinion and the policy decisions should become apparent. U.S. involvement in Vietnam began during the Eisenhower administration in November of $1955 .{ }^{35}$ Initially, U.S. involvement played a strictly supportive role, not a military one. In Eisenhower's Annual Budget Message to the Congress for the Fiscal Year of 1956, he proposed to "furnish defense support to several countries" in Southeast Asia, Vietnam included. ${ }^{36}$ This was in response to the general fear of Communist subversion at the

\footnotetext{
33 "Anti-War Sentiment Dominates Talk Airwaves," Pew Research Journalism Project, August 30, 2007.

${ }^{34}$ Lyndon B. Johnson: "Annual Message to the Congress on the State of the Union," January 12, 1966. Online by Gerhard Peters and John T. Woolley, The American Presidency Project.

${ }^{35}$ U.S. Department of Defense. Press Operations. "Name of Technical Sergeant Richard B. Fitzgibbon to be Added to the Vietnam Veterans Memorial." (November 6, 1998).

${ }^{36}$ Dwight D. Eisenhower: "Annual Budget Message to the Congress: Fiscal Year 1956," January 17, 1955. Online by Gerhard Peters and John T. Woolley, The American Presidency Project.
} 
time. ${ }^{37}$ The prevailing belief of foreign policy elites was the Domino Theory, which theorizes that in order to prevent fighting at home the U.S. must engage the Communist ideal in foreign countries, lest the weaker states fall and Communism comes knocking on the U.S.'s doorstep. ${ }^{38}$ Due to this fear of Communism, those who were informed generally accepted the assistance to a number of Southeast Asian countries that Eisenhower had proposed, but the majority of U.S. citizens were unaware of the involvement at all. ${ }^{39}$ Due to this lack of an informed public, the public opinion of such a policy was irrelevant to the policy elites at the time, since there simply was not one. The lack of an obvious public opinion lead most policy leaders to believe that a policy of assistance to these countries was one that was supported by most. This was seen in the next administration, when President John F. Kennedy informed the President of the Republic of Vietnam that the U.S. would promptly increase the assistance to the Vietnamese defense effort in $1961 .^{40}$ Yet this ambiguity of the public towards Vietnam policy would soon change.

The development of a public opinion towards U.S. involvement in Vietnam took off during the Johnson administration. At the onset of his administration, President Lyndon B. Johnson followed his predecessors' example, only gradually increasing the support sent to Vietnam. ${ }^{41}$ By 1965 the President was "convinced that the country, for the most part, [was] with him; that there [was] only a small minority dissent from his Vietnam policies." ${ }^{42}$ This belief led the President to continue with the Vietnam policy that he deemed appropriate, increasing the extent of U.S. involvement in the war by authorizing air strikes on military targets

\footnotetext{
37 Ibid.

${ }^{38}$ Jean Collins, "The Domino Theory," The North American Review, Vol. 252, No. 3 (May, 1967): 19-20.

39 William L. Lunch and Peter W. Sperlich, "American Public Opinion and the War in Vietnam," The Western Political Quarterly, Vol. 32, No. 1 (March, 1979): 21-44.

${ }^{40}$ John F. Kennedy: "Exchange of Messages With the President of the Republic of Viet-Nam.," December 15, 1961. Online by Gerhard Peters and John T. Woolley, The American Presidency Project.

${ }^{41}$ Lyndon B. Johnson, "Annual Budget Message to the Congress, Fiscal Year 1965," January 21, 1964. Online by Gerhard Peters and John T. Woolley, The American Presidency Project.

${ }^{42}$ Lester Markel, "Public Opinion and the War in Vietnam," The New York Times, August 8, 1965 .
} 
and increasing the U.S. fighting force to 190,000 men. ${ }^{43}$ In the same speech, Johnson addressed the American people with a forceful statement; "The days may become months, and the months may become years, but we will stay as long as aggression commands us to battle," a statement that was a prelude to the arduous future of the war. ${ }^{44}$ It seems that this was an example in which policy elites were influenced by the public opinion, yet this is not the case, as the belief in the support of the majority that Johnson held was an inaccurate one. An article published in The New York Times on March 27, 1966 reported, "many thousands took part in demonstrations during the day" in a number of large cities throughout the U.S. ${ }^{45}$ In New York City, there were between 20,000 and 25,000 marchers on Fifth Avenue alone. ${ }^{46}$ Protests were taking place in other cities around the country on that same day, likely with similar numbers. It would be a mistake to consider an active vocal group numbering in the tens of thousands as a "small minority of dissent." ${ }^{47}$ A study done by the Gallup organization the following year found that a majority of respondents to a survey disapproved of the way that President Johnson was handling the situation in Vietnam, ${ }^{48}$ further showing the inaccuracy in the amount of support for President Johnson. Even as evidence was presented that suggested the policy choices that the President made were not following the policy decisions the public wanted, Johnson remained steadfast on his policy choices. In his State of the Union Address in 1968, Johnson outlined how increased support for the war was needed and authorized the deployment of additional 13,500 men, only weeks after he had sent about 11,000 additional Marine and airborne troops. ${ }^{49}$ This decision made by the President shows just how ineffective public opinion was at influencing U.S. foreign policy during this administration.

\footnotetext{
43 Johnson, "State of the Union." (1966).

${ }^{44}$ Ibid.

${ }^{45}$ Douglas Robinson, “Thousands on Fifth Ave. March in Vietnam Protest," The New York Times, March 27, 1966.

46 Ibid.

47 Markel, "Public Opinion and the War in Vietnam."

48 Gallup Organization, “Gallup Poll \# 1967-0742: Vietnam War/1968 Presidential Election," March 9-14, 1967.

${ }^{49}$ Lyndon B. Johnson, "The President's Address to the Nation Announcing Steps To Limit the War in Vietnam and Reporting His Decision Not To Seek Reelection," March 31, 1968. Online by Gerhard Peters and John T. Woolley, The American Presidency Project.
} 
As the Nixon administration took over, many members of the public hoped that Nixon would simply end the war immediately by ordering the U.S. forces home. ${ }^{50}$ Yet Nixon did not do this, stating, "I would have betrayed my solemn responsibility as President of the United States if I had done so." ${ }^{11}$ This is an extremely telling quote, as it gives insight into the mindset of foreign policy elites. According to Nixon, adhering to the whims of the public opinion, concerning foreign policy, is a terrible thing for the country as a whole. This is counter to the prevailing popular belief in Democratic Theory, in which the public should be an important actor in governmental decision-making. ${ }^{52}$ If policy elites share this belief, it might explain why public opinion is ineffective in influence U.S. foreign policy.

By 1971, it was common knowledge among the public and policy elites that polling data showed an overwhelming majority of Americans wanted the troops out of Vietnam by the end of the year, with a staggering $75 \%$ of people reputing the President's policy. ${ }^{53}$ Even with such a large majority of the American public calling for an end to the war in Vietnam, it persisted through the rest of the Nixon administration and into the Ford administration. U.S. involvement in Vietnam did not end until President Gerald Ford announced on April 29, 1975 that "the military situation in the area [Saigon] deteriorated rapidly... I therefore ordered the evacuation of all American personnel remaining in South Vietnam." 54 The public had finally achieved what they wanted, after voicing their opinion for over a decade. It is clear that during the Vietnam War public opinion was at best commentary about the war, with little influence over foreign policy formulation. Instead, the policies made by policy elites during the war were the policies they deemed most appropriate, regardless of the public opinion. President Nixon stated this in a response to a letter he received from a university student, "the policies we are now following reflect our own best judgment,

\footnotetext{
${ }^{50}$ Richard Nixon, "Address to the Nation on Vietnam," May 14, 1969. Online by Gerhard Peters and John T. Woolley, The American Presidency Project.

51 Ibid.

52 "American Public Says Government Leaders Should Pay Attention to Polls," World Public Opinion.org.

53 Reo M. Christenson, "Vietnam and Public Opinion," The New York Times July 3, 1971.

${ }^{54}$ Gerald R. Ford, "Statement Following Evacuation of United States Personnel From the Republic of Vietnam," April 29, 1975. Online by Gerhard Peters and John T. Woolley, The American Presidency Project.
} 
based on exhaustive study of all the available evidence, of how to achieve that goal. To abandon that policy merely because of a public demonstration would therefore be an act of gross irresponsibility on my part." ${ }^{25}$ This sentiment would persist through many administrations, guiding executives like George W. Bush to continually disregard the majority public opinion in favor of the policy elite throughout his involvement in the Iraq War.

\section{The Iraq War}

The Iraq War is another important case study to examine as it shares many similarities with the Vietnam War, such as a supportive public in the beginning with a quick shift to public dissatisfaction as the war wore on. Meanwhile, policy elites and administration officials remained steadfast in their commitment to see the war through, claiming the fighting was for democratic principles just as their predecessors did forty years before. ${ }^{56} \mathrm{~A}$ key difference, however, between the two conflicts is the fact the onset of the Iraq War was brought on by the terrorist attacks carried out on September 11, 2001 against the United States, while there was no attack on U.S. soil before the Vietnam War. ${ }^{57}$ Another key difference is that the Vietnam War spanned across four different administrations, while the Iraq War only spanned two. It is important to shed light on these differences as they have implications on the mood of the public opinion, and therefore are an important aspect of this research. In order to understand the relationship shared between U.S. foreign policy and the public opinion it will again be important to continue through this case study chronologically. Again, this will help to illustrate the cause and effect relationship between public opinion and foreign policy decisions.

As stated before, the catalyst of the Iraq War was the 9/11 terrorist attacks in New York City. It was originally believed that Iraq and the Hussein regime

\footnotetext{
${ }^{55}$ Richard Nixon, "Letter to University Student Randy J. Dicks on the "Vietnam Moratorium," October 13, 1969. Online by Gerhard Peters and John T. Woolley, The American Presidency Project.

${ }^{56}$ George W. Bush, "Remarks on Signing the Emergency Supplemental Appropriations Act for Defense and for the Reconstruction of Iraq and Afghanistan, 2004," November 6, 2003. Online by Gerhard Peters and John T. Woolley, The American Presidency Project.

${ }^{57}$ George W. Bush, "Address to the Nation on Iraq," March 17, 2003. Online by Gerhard Peters and John T. Woolley, The American Presidency Project.
} 
had supported al-Qaeda to some capacity in carrying out the attack, ${ }^{58}$ and that it was working to acquire weapons of mass destruction (WMDs). ${ }^{59}$ Due to the passage of the "Joint Resolution to Authorize the use of United States Armed Forces against Those Responsible for the Recent Attacks Launched against the United States," the president had the authority to "take military action against any nation, organization, or persons that had been involved in the 9/11 attacks." ${ }^{60}$ The Bush administration was determined to include Iraq in this group, and in his 2002 State of the Union Address, Bush began his campaign to do this. In his speech he labeled Iraq as a member of a new "axis of evil" consisting of states aimed at threatening the peace of the world. ${ }^{61}$ He would continue to define how big of a threat Hussein was to the United States throughout the year, until, on October $10^{\text {th }}$ and $11^{\text {th }}$, Congress passed the "Authorization for Use of Military Force Against Iraq Resolution of 2002." ${ }^{2}$ By March of the following year, the United States had begun military operations in Iraq, ${ }^{63}$ and by May of that same year, President Bush announced that, "major combat operations in Iraq have ended" from the deck of the U.S.S. Abraham Lincoln. ${ }^{64}$

So what was going through the minds of the American public throughout this period of quick, policy decisions? Well, in general, most of the public

${ }^{58}$ George W. Bush, "Letter to the Speaker of the House of Representatives Transmitting a Supplemental Appropriations Request for Ongoing Military and Intelligence Operations in Iraq, Afghanistan, and Elsewhere," September 17, 2003. Online by Gerhard Peters and John T. Woolley, The American Presidency Project.

${ }^{59}$ George W. Bush, "Address Before a Joint Session of the Congress on the State of the Union,” January 29, 2002. Online by Gerhard Peters and John T. Woolley, The American Presidency Project.

${ }^{60}$ Ole R. Holsti, American Public Opinion on the Iraq War (University of Michigan Press, November 2011).

${ }^{61}$ Bush, "Address before a Joint Session of Congress on the State of the Union," 2002.

${ }^{62}$ U.S. Congress. House of Representatives. International Relations Committee. 2002. $A u$ thorization for Use of Military Force Against Iraq Resolution of 2002. $107^{\text {th }}$ Congress, Second Session, October $10-11$ and October 16.

63 George W. Bush, "Address to the Nation on Iraq," March 19, 2003. Online by Gerhard Peters and John T. Woolley, The American Presidency Project.

${ }^{64}$ George W. Bush, "Address to the Nation on Iraq From the U.S.S. Abraham Lincoln," May 1, 2003. Online by Gerhard Peters and John T. Woolley, The American Presidency Project. 
was supportive of the policy, with Bush's approval rating reaching a peak of $76 \%$ after the fall of Baghdad. ${ }^{65}$ It was easy for the public to support such a foreign policy since the war effort was to prevent Iraq from acquiring WMDs, further the growing "global war on terrorism," ${ }^{66}$ and promote democracy. ${ }^{67}$ This might suggest a causal relationship between the public opinion and the policy decisions made, however causality is not present. The policies made by the Bush administration at the onset of the Iraq War were not in response to public polling data, but rather policies the administration wanted to pursue. ${ }^{68}$ Paul Wolfowitz, the United States Deputy Secretary during the first term of the Bush administration, stated, "We settled on [WMDs as the core reason to go to war because] everyone could agree." ${ }^{69}$ It was not as though the public believed Iraq had WMDs and then pressured their elected officials to pursue a more aggressive policy, but rather the elected officials framing their policy so "everyone could agree." ${ }^{70}$ However, this massive support would not last, and as of 2004, Bush's approval rating began a slow, consistent, decline. ${ }^{71}$

At the beginning of 2004, public opinion for the Iraq War was positive, with between $54 \%$ and $58 \%$ saying that the war was not a mistake. ${ }^{72}$ Five months later, after the announcement that the U.S. would transfer sovereignty back to Iraq, polling data found that the percent of Americans in support of the war had fallen to $46 \%{ }^{73}$ A large majority of the public believed that the transfer of power was a sign that U.S. policy was failing because the transfer occurred before the U.S. could bring about stability in the country. ${ }^{74}$ When asked how long they thought the U.S. should have a significant number of troops in Iraq,

\footnotetext{
${ }^{65}$ Joseph Carroll, “The Iraq-Vietnam Comparison,” Gallup Organization, June 15, 2004.

${ }^{66}$ Holsti, American Public Opinion on the Iraq War

${ }^{67}$ Bush, "Remarks on Singing the Emergency..." 2003.

${ }^{68}$ Holsti, American Public Opinion on the Iraq War

69 Ibid.

${ }^{70}$ Ibid.

${ }^{71}$ Carroll, "The Iraq-Vietnam comparison"

${ }^{72}$ Ibid.

${ }^{73}$ Lydia Saad, "Americans Applaud Transfer of Sovereignty to Iraq: Have mixed expectations for future of Iraq," Gallup Organization, June 29, 2004.

${ }^{74}$ Ibid.
} 
the study found that a majority said less than a year. ${ }^{75}$ By the end of the year, a majority of people disapproved of the United States' decision to go to war with Iraq. ${ }^{76}$ The quick decline in public approval for the Iraq war is likely due to the lack of any evidence suggesting Iraq had WMDs and revelations made by the 9/11 Commission. In October of 2003, David Kay, the head of the group responsible for locating WMDs in Iraq, gave a preliminary report to Congress in which he stated that his inspection team had failed to find any WMDs in the country. ${ }^{77}$ The summer of the next year, the 9/11 Commission found that there was "no credible evidence that Iraq and al Qaeda had cooperated on attacks against the U.S." ${ }^{78}$ These findings showed that the Bush administration was incorrect when they began to formulate the Iraq policy that would define the decade. These blunders of the administration are likely what led to the quick change in public opinion.

By 2005, the growing public opinion was that the war in Iraq was going badly for the United States. ${ }^{79}$ Regardless, the Bush administration pushed on with their Iraq policy. In an interview on CNN, then Vice President Dick Cheney stated, "we'll leave as soon as the task is over with." ${ }^{80}$ President Bush continued in this rhetoric when he said, "we're not leaving, so long as I'm the President." ${ }^{11}$ The true effect or lack thereof, that public opinion had on foreign policy during the Iraq War is evident when listening to Bush's own words regarding the matter, "I don't think you've ever heard me say, 'Gosh, I'd better change position because the polls say this or that'... I'm going to do what I think is right, and if people don't like me for it, that's just the way it is." ${ }^{82}$ This idea became practice when Bush committed an additional 20,000 American

\footnotetext{
75 Ibid.

${ }^{76}$ Jeffrey M. Jones, "Public's Evaluation of Iraq War Grows More Negative: Americans still divided over decision to go to war," The Gallup Organization, December 22, 2004.

77 Holsti, American Public Opinion on the Iraq War

${ }^{78}$ Ibid.

79 Joseph Carroll, "Americans' Views of the Iraq War Sour: President Bush's approval ratings on Iraq hold Steady at 42\%," The Gallup Organization, May 5, 2005.

${ }^{80}$ Dick Cheney, interview by Larry King, CNN Larry King Live, May 30, 2005.

${ }^{81}$ George W. Bush, “The President's News Conference,” August 21, 2006. Online by Gerhard Peters and John T. Woolley, The American Presidency Project.

82 Ibid.
} 
troops and an additional carrier strike group to Iraq, ${ }^{83}$ even as polling data showed that $60 \%$ of Americans believed that originally sending troops to Iraq was a mistake, ${ }^{84}$ and a majority believed that U.S. troops should be withdrawn from Iraq within a year. ${ }^{85}$ It was not until the end of 2008 that Bush finally announced a decrease in the U.S. military presence, when he stated, "Iraqi forces will now take the lead in security operations in Anbar, with American troops moving into an over-watch role." ${ }^{\text {86 }}$

De-escalation of U.S. military involvement in Iraq began when President Barack Obama took office in 2009. In a speech given at Camp Lejeune, North Carolina, the President announced that the U.S. combat mission would end by August 31, 2010, leaving only transitional forces to be removed by the end of $2011 .^{87}$ The war was finally over on December 15, 2011 when the President announced that the troops were preparing to make their final march out of the country. ${ }^{88}$ The Iraq War is evidence of the ineffectiveness that public opinion truly has on U.S. foreign policy. For half of Bush's Presidency, the policy decisions he was making were the policy choices that the majority public opinion didn't want. Perhaps because of this, "nearly two-thirds say his administration will be remembered more for its failures than its accomplishments." ${ }^{99}$

\section{Implications}

The ineffectiveness that public opinion has on U.S. foreign policy is telling of the future of how the U.S. public, and the world, views U.S. foreign policy. As other states make gains in catching up to the United States in terms of

\footnotetext{
${ }^{83}$ George W. Bush, "Address to the Nation on Military Operations in Iraq," January 10, 2007. Online by Gerhard Peters and John T. Woolley, The American Presidency Project.

${ }^{84}$ Jeffrey M. Jones, "Opposition to Iraq War Reaches New High: Sixty-three percent say U.S. made mistake in sending troops," The Gallup Organization, April 24, 2008.

${ }^{85}$ David W. Moore, "Three Years of war Have Eroded Public Support: majority of Americans want U.S. troops home within a year," The Gallup Organization, March 17, 2006.

${ }^{86}$ George W. Bush, "Statement on the War on Terror in Iraq," September 1, 2008. Online by Gerhard Peters and John T. Woolley, The American Presidency Project.

${ }^{87}$ Barack Obama, "Remarks on Military Operations in Iraq at Camp Lejeune, North Carolina," February 27, 2009. Online by Gerhard Peters and John T. Woolley, The American Presidency.

${ }^{88}$ Barack Obama, "The President's Weekly Address," December 17, 2011. Online by Gerhard Peters and John T. Woolley, The American Presidency Project.

89 Keeter, "Trends in Public Opinion about the War in Iraq, 2003-2007."
} 
hegemonic power, the U.S. attempts to retain their unipolar status, most notably with the "pivot to Asia," which is "aimed at increasing America's influence in Asia" to counter a growing China. ${ }^{90}$ At the same time, the United States has the ongoing mission of spreading democracy and the ideals that are a part of it. ${ }^{91}$ This is clear when looking at the case studies presented in this paper, for administrations in both the Vietnam ${ }^{92}$ and $\operatorname{Iraq}^{93}$ war claimed a large part of the war effort was to spread democracy. Due to the fact that these are important policy issues for the United States, the foreign policy decisions made in the future will become ever important.

The future importance of foreign policy decisions reveal the inaccuracy of the conventional wisdom that public opinion should and does have a large amount of influence over U.S. foreign policy decisions. . It is clear from the research findings that policy elites do not adhere to the will of the people when it comes to foreign policy decisions, but rather, "must necessarily engage in the process of 'manufacturing consent' from the public." 94 This "manufactured consent" is highlighted by Ole R. Holsti, who wrote, "policies are chosen beforehand, polls used to spin them." ${ }^{95}$ The idea presented here shows just how policy is formed without thinking of the public opinion. In fact, according to Holsti, the only important thing that the public opinion is good for is learning how to sell policy decisions to the public. This "manufactured consent" is evidence that decision-making is becoming more concentrated in the power elite. The power elite is extremely under representative of the public, as it is comprised of industry leaders from political, economic, and military sectors. ${ }^{96}$ These members consider each other as "among those who count," ${ }^{97}$ effectively stating that the public does not count, and therefore the

\footnotetext{
${ }^{90}$ David Nakamura, "On Asia trip, Obama makes the case for U.S. relevance - and his own," The Washington Post, November 15, 2014.

${ }^{91}$ Ibid.

92 Johnson, "Annual Message to the Congress on the State of the Union."

93 Bush, "Remarks on Signing the Emergency Supplemental Appropriations Act for Defense and for the Reconstruction of Iraq and Afghanistan, 2004"

94 Walter Lippmann, Public Opinion (New York: Macmillan, 1992).

${ }_{95}$ Holsti, American Public Opinion on the Iraq War.

96 Wright, The Power Elite

97 Ibid.
} 
public opinion does not count or matter. As the decision makers of foreign policy become more concentrated in the "power elite," the foreign policy decisions will become less representative of the public. This will cause the future of U.S. foreign policy to resemble an oligarchy rather than a democracy, potentially a hindrance to the United States' ability to spread democratic ideals overseas. It is clear from the research presented that public opinion is not at all effective at influencing U.S. foreign policy. 